\title{
SELF-ESTEEM OF GRADE 9 STUDENTS IN DRESSMAKING
}

\author{
Mrs. Josie G. Bueno \\ Magdalena Integrated National High School, Division of Laguna, Magdalena Laguna, Philippines
}

Article DOI: https://doi.org/10.36713/epra9398

DOI No: 10.36713/epra9398

\begin{abstract}
Confidence in one's value as a human being is a precious psychological resource and generally a highly positive factor in life; it is correlated with achievement, good relationships, and satisfaction asserted by Kraybill (2018). Possessing little self-regard can lead people to become depressed, to fall short of their potential, or to tolerate abusive relationships and situations.

Grade 9 students are not really interested in dressmaking they find it hard to learn this area the researcher wants to know the self-esteem among Grade 9 students in dressmaking to help them overcome and find the reasons behind it.

The respondents of the study were ninety-eight (98) from Grade 9 students. It was limited only in three (3) questions. It was qualitative and quantitative designs through interview and using percentage for presentation of the result.

The self-esteem of Grade 9 students with regards to dressmaking has total of $95.42 \%$ answered no, $2.76 \%$ answered yes and $1.9 \%$ answered maybe. Based on the result of the interview by the researcher the Grade 9 students were not interested in dress making, their self-esteem towards dressmaking was low.

The reasons of the students why they did not take the dressmaking first in the list was boring with $35.11 \%$, second was difficult with $19.47 \%$, third was not interested with $17.18 \%$, fourth was not in demand with $14.50 \%$, fifth was no career opportunity and the last was scared with $3.82 \%$ with the total of $100 \%$.

After the strategy used by the researcher the self-esteem of the students increases in choosing the dressmaking, from $95.42 \%$ down to $80.92 \%$ with the difference of $14.5 \%$ answered "no", from $2.76 \%$ increased to $9.17 \%$ with the difference of $6.41 \%$ answered yes, while the students answered "maybe" from $1.9 \%$ to $9.92 \%$ with the difference of $8.02 \%$.

The researcher concluded that the Grade 9 students need to have orientation about the dressmaking and allow them to do hands-on activity to become more familiar before they choose which course to take in Grade 9 on their TLE. Various aspects of the class can be examined, such as routines, use of time, schedule, participation, teaching strategies, management strategies, learner interest, and much more. A teacher will naturally look for support on an issue that is difficult for him or her, but it is often a great method of being exposed to a new and different approach to teaching.
\end{abstract}

\section{I.CONTEXT AND RATIONALE}

Confidence in one's value as a human being is a precious psychological resource and generally a highly positive factor in life; it is correlated with achievement, good relationships, and satisfaction asserted by Kraybill (2018). Possessing little selfregard can lead people to become depressed, to fall short of their potential, or to tolerate abusive relationships and situations.

Grade 9 students are not really interested in dressmaking they find it hard to learn this area the researcher wants to know the self-esteem among Grade 9 students in dressmaking to help them overcome and find the reasons behind it.

\section{II.REVIEW OF RELATED LITERATURE}

Baumeister (2003) found out that the modest correlations between self-esteem and school performance do not indicate that high self-esteem leads to good performance. Instead, high self-esteem is partly the result of good school performance. Efforts to boost the self-esteem of pupils have not been shown to improve academic performance and may sometimes be counterproductive. Job performance in adults is sometimes related to selfesteem, although the correlations vary widely, and the direction of causality has not been established. Occupational success may boost self-esteem rather than the reverse. Alternatively, self-esteem may be helpful only in some job contexts. Laboratory studies 
have generally failed to find that self-esteem causes good task performance, with the important exception that high self-esteem facilitates persistence after failure.

\section{III.RESEARCH QUESTION}

1. What is the self-esteem of Grade 9 students with regards to dressmaking?

2. What are the reasons why Grade 9 students did not choose dressmaking?

3. What is the strategy used to increase the self-esteem of Grade 9 on dressmaking?

\section{SCOPE AND LIMITATION}

The respondents of the study were ninety-eight (98) from Grade 9 students. It was limited only in three (3) questions. It was qualitative design through interview.

\section{METHODOLOGY}

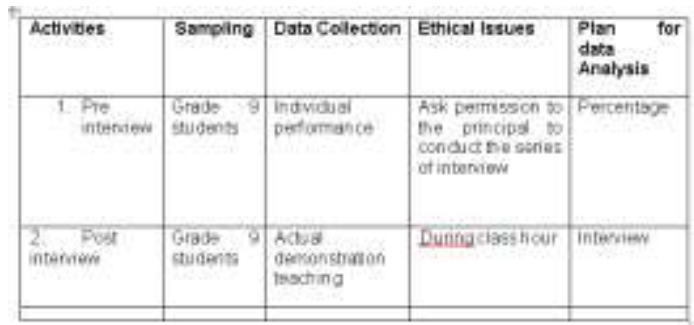

VI. TIME TABLE

\begin{tabular}{|l|l|}
\hline ACTIVITIES & TIME FRAME \\
\hline Pre interview & July, 2019 \\
\hline Actual Demonstration & Every Friday \\
\hline Post interview & February, 2020 \\
\hline
\end{tabular}

VII. COST ESTIMATED

\begin{tabular}{|l|l|}
\hline ACTIVITIES & COST ESTIMATES \\
\hline Actual demonstration & 500 Per laboratory \\
\hline
\end{tabular}

\section{PLANS FOR DISSEMINATION} AND ADVOCACY

\begin{tabular}{|c|c|c|c|}
\hline $\begin{array}{l}\text { TARGET } \\
\text { DATE }\end{array}$ & $\begin{array}{l}\text { PERSONS } \\
\text { MVOLVED }\end{array}$ & ACTION TAKEN & EXPECTED RESUT \\
\hline $\begin{array}{l}\text { School } \\
\text { Yesr } 2019 \\
-2020\end{array}$ & $\begin{array}{l}\text { - Atficor-in } \\
\text {-chargo } \\
\text { - Grade } 9 \\
\text { - The } \\
\text { resourcher }\end{array}$ & 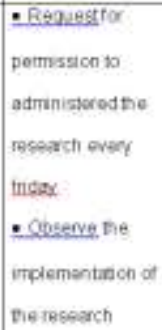 & 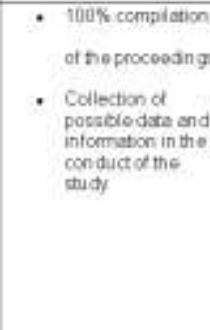 \\
\hline
\end{tabular}

DO 32, s. 2017 - Gender-Responsive Basic

Education Policy

The Department of Education (DepEd) issues the enclosed Gender-Responsive Basic Education Policy in line with its Gender and Development (GAD) mandate as stipulated in the 1987 Philippine
Constitution, Republic Act (RA) No. 9710 or the Magna Carta of Women (MCW), RA 10533 or the Enhanced Basic Education Act of 2013, and the Philippines' International Human Rights Commitments to the Universal Declaration of Human Rights (UDHR), Convention on the Elimination of All Forms of Discrimination Against Women (CEDAW), and the Convention on the Rights of the Child (CRC) among others

\section{FINDINGS}

The table showed that among six (6) sections with two hundred sixty-two (262) Grade 9

The self-esteem of Grade 9 students in regards on dressmaking (pre interview)

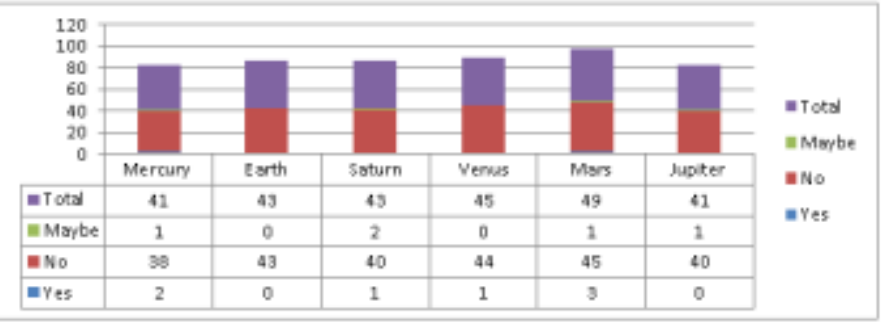

students, seven (7) answered yes, that they want dressmaking, while two hundred fifty (250) answered no and five (5) answered maybe.

In Grade 9 Mercury 93\% answered no, while $5 \%$ answered yes and $2 \%$ maybe. Grade 9 Earth has $100 \%$ answered no, while in Grade 9 Saturn there are $93 \%$ who answered no, $5 \%$ for yes and $2 \%$ for maybe. In Grade 9 Venus $98 \%$ answered no and $2 \%$ for yes, while in Grade 9 Mars $92 \%$ answered no, $6 \%$ for yes and $2 \%$ for maybe. About $98 \%$ of Grade Jupiter answered no and $2 \%$ yes. With the total of $95.42 \%$ answered no, $2.76 \%$ answered yes and 1.9 answered maybe.

Based on the result of the interview by the researcher the Grade 9 students were not interested in dressmaking their self-esteem towards dress making was low.

The reasons why the Grade 9 students did not choose the dressmaking

\begin{tabular}{|c|c|c|c|}
\hline Reasons & No. of students & Percentage & Rank \\
\hline aboring & 92 & $35.11 \%$ & $1^{10 t}$ \\
\hline bnot interested & 45 & $1718 \%$ & $3^{\text {a }}$ \\
\hline crnot in demand & 38 & $1450 \%$ & $4^{5}$ \\
\hline d difficul & 51 & $1947 \%$ & $2^{\text {nes }}$ \\
\hline e scared & 10 & $382 \%$ & ब9 \\
\hline $\begin{array}{l}\text { fno career } \\
\text { oppontunity }\end{array}$ & 26 & $992 \%$ & 5 \\
\hline Total & 262 & $900 \%$ & \\
\hline
\end{tabular}

Out of two hundred sixty-two (262) respondents the most reasons revealed were: 
The table showed the reasons of the students why did not take the dressmaking first in the list was boring with $35.11 \%$, second was difficult with $19.47 \%$, third was not interested with $17.18 \%$, fourth was not in demand with $14.50 \%$, fifth was no career opportunity and the last was scared with $3.82 \%$ with the total of $100 \%$.

The strategy used to increase the self-esteem of Grade 9 on dressmaking

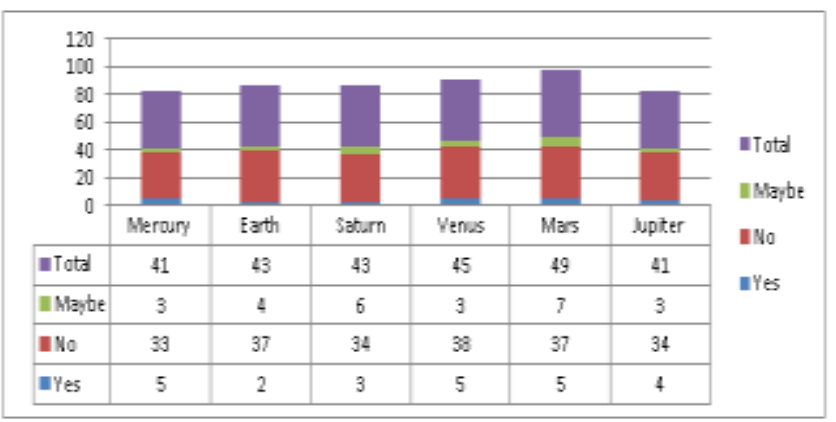

Based on the result of the interview by the researcher, the researcher herself used the series of actual demonstration and discussion about dressmaking so that the students will be informed about dressmaking and the result of the post interview increased but still with few numbers.

The table showed that among six (6) sections with two hundred sixty-two (262) Grade 9 students there are twenty-four (24) who answered "yes" that they want dressmaking, while two hundred twelve (212) answered "no" and twenty (26) answered "maybe".

In Grade 9 Mercury $80.49 \%$ answered no, $12.20 \%$ answered yes and $7.32 \%$ maybe, while Grade 9 Earth has $86.05 \%$ answered "no", 9.30\% answered yes and $4.65 \%$ answered maybe. $79.07 \%$ of Grade 9 Saturn answered no, $6.98 \%$ for yes and $13.95 \%$ for maybe. Grade 9 Venus has $84.44 \%$ answered no, $11.11 \%$ for no $6.66 \%$ for maybe and Grade 9 Mars has $75.51 \%$ answered no, $10.20 \%$ for yes and $14.28 \%$ for maybe, while the Grade 9 Jupiter answered $82.93 \%$ no and $9.76 \%$ yes 7.32 for maybe. With the total of $80.92 \%$ answered no, $9.16 \%$ answered yes and $9.92 \%$ answered maybe.

The

\begin{tabular}{l} 
interview \\
\hline
\end{tabular}

The table showed that after the strategy was used by the researcher the self-esteem of the students increases in choosing the dressmaking from $95.42 \%$ down to $80.92 \%$ with the difference of $14.5 \%$ answered "no", from $2.76 \%$ increased to $9.17 \%$ with the difference of $6.41 \%$ answered yes, while the students answered "maybe" from $1.9 \%$ to $9.92 \%$ with the difference of $8.02 \%$.

It showed that the Grade 9 students were not well inform and lack of actual experience in dress making. Revealed by Leary (2016) that classroom Observation explores the pivotal role of lesson observation in the training, assessment and development of new and experienced teachers. Offering practical guidance and detailed insight on an aspect of training that is a source of anxiety for many teachers, this thought-provoking book offers a critical analysis of the place, role and nature of lesson observation in the lives of education professionals.

\section{CONCLUSION}

The researcher concluded that the Grade 9 students need to have orientation about the dressmaking and allow them to do hands-on to become more familiar before they choose which course to be taken in Grade 9 on their TLE. Various aspects of the class can be examined, such as routines, use of time, schedule, participation, teaching strategies, management strategies, learner interest, and much more. A teacher will naturally look for support on an issue that is difficult for him or her, but it is often a great method of being exposed to a new and different approach to teaching.

\section{REFERENCES}

1. Odelya Gertel Kraybill Ph.D. on September 30, 2020 in Expressive Trauma Integration

2. Roy F. Baumeister (2003 Does High SelfEsteem Cause Better Performance, Interpersonal Success, Happiness, or Healthier Lifestyles?

3. https://www.psychologytoday.com/intl/basic s/self-esteem 